\title{
Pelatihan Desain Situs Web Sekolah pada SMA Brigjend Katamso Medan dengan menggunakan Adobe Dreamweaver
}

\author{
Paulus $^{1}$, Rin Rin Meilani Salim², Sophya Hadini Marpaung ${ }^{3}$ \\ 1,2,3Program Studi Sistem Informasi, STMIK Mikroskil \\ *e-mail: paulus@mikroskil.ac.id¹, rinrin.meilani@mikroskil.ac.id², sophya.marpaung@mikroskil.ac.id³
}

\begin{abstract}
This community service activity is intended to train the high school students in dealing with technological developments, namely by introducing the basic web skills to start designing their school website. This two days training was held in the SMA Brigjend Katamso computer laboratory. Before participating in the training, students did a pretest to measure their understanding and initial ability. Then the students were given e-modules and did web design using Adobe Dreamweaver. The community service team chose Adobe Dreamweaver because it provides ease of design without memorizing HTML tags or learning other markup languages. After that, the students were allowed to design their school website. In the end, students did a posttest and fill a questionnaire to measure training success. Comparison of average pretest score and average posttest score showed an increase in the understanding and ability of the students. In addition, questionnaire results showed that the students were satisfied with the training.
\end{abstract}

Keywords: service, community, design, website, school

\begin{abstract}
Abstrak
Kegiatan pengabdian pada masyarakat ini ditujukan untuk membekali siswa-siswi pelatihan dalam menghadapi perkembangan teknologi yaitu dengan pengenalan ilmu web dasar yang semakin dibutuhkan di tingkat sekolah menengah dengan harapan, siswa-siswi mampu mendesain rancangan situs web sekolah. Pelatihan ini dilaksanakan selama dua hari di laboratorium SMA mitra. Sebelum mengikuti pelatihan siswasiswi diberikan pretest untuk mengukur pemahaman dan kemampuan awal. Kemudian siswa-siswi diberikan e-modul dan diajarkan desain situs web menggunakan Adobe Dreamweaver. Tim pengabdian pada masyarakat memilih Adobe Dreamweaver karena aplikasi tersebut memberikan kemudahan mendesain tanpa perlu menghapal tag-tag HTML maupun mempelajari bahasa markah lainnya. Setelah itu, siswa-siswi diberikan kesempatan secara mandiri mendesain situs web sekolah mereka. Di akhir kegiatan pelatihan, siswa-siswi diminta untuk mengisi posttest dan kuesioner untuk mengukur keberhasilan pelatihan. Hasil ratarata nilai pretest dan rata-rata nilai posttest menunjukkan peningkatan pemahaman dan kemampuan siswasiswi sekolah mitra kali ini. Di samping itu, hasil penilaian kuesioner juga menunjukkan siswa-siswi puas dengan pelatihan yang diberikan.
\end{abstract}

Kata kunci: Pengabdian, Masyarakat, Desain, Situs Web, Sekolah

\section{PENDAHULUAN}

Perkembangan teknologi yang semakin pesat mempengaruhi berbagai bidang kehidupan. Munculnya website merupakan salah satu dampak dari perkembangan tersebut. Website menjadi salah satu media yang banyak digunakan oleh berbagai kalangan untuk mengakses beragam informasi. Dengan pencarian informasi yang mudah melalui pemanfaatan website bahkan setiap orang dimungkinkan untuk memiliki website. Hal ini didukung dengan berbagai kemudahan dalam merancang dan mengembangkan sebuah website menggunakan aplikasi, Di sisi lain, berbagai hostingan gratis dan murah juga banyak beredar. Dilatarbelakangi dengan perkembangan teknologi tersebut, kali ini tim pengabdian akan melakukan pengabdian kepada masyarakat dengan pembekalan pelatihan web dasar pada SMA Brigjend Katamso.

Yayasan Perguruan Nasional Brigjend Katamso adalah badan yang menyelenggarakan pendidikan di tingkat PG/TK, SD, SMP, SMA dan SMK. Salah satu unit sekolahnya, yaitu SMA Brigjend Katamso yang sudah terakreditasi A. Dari data yang diperoleh dari laman Kemdikbud.go.id (Kemdikbud, 2020) SMA ini mengasuh 977 siswa. Dengan predikat "A" tersebut, SMA Brigjend Katamso tentunya sangat memperhatikan berbagai bidang, seperti: proses 
pembelajaran, kegiatan ekstrakurikuler, dan lainnya. Berdasarkan laman web SMA Brigjend Katamso juga dinyatakan bahwa selama tahun 2019, SMA Brigjend Katamso telah meraih 21 prestasi (Katamso, 2020). Mayoritas prestasi tersebut adalah prestasi di bidang olahraga, dan tidak ada prestasi yang terkait dengan teknologi informasi. Padahal di era digital saat ini, teknologi informasi betul-betul masuk dalam kehidupan banyak orang, terutama kaum muda seperti yang dijelaskan pada sebuah artikel tentang literasi digital, bahwa website sudah bisa digunakan didunia pendidikan terutama untuk proses belajar mengajar setiap hari (Hendra Kurniawan, 2019).

SMA Brigjend Katamso sudah mengajarkan pelajaran komputer di sekolah, akan tetapi pembelajarannya hanya sebatas desain grafis, siswa belum diajarkan materi desain web. Sementara, salah satu sekolah pesaingnya yang juga berada dibawah naungan Yayasan Perguruan Nasional Brigjend Katamso yaitu SMK Brigjend Katamso, selama tahun 2019, SMK ini telah meraih 4 prestasi yang cukup menonjol dalam kompetisi desain web (Dapodikbud, 2020). Pelajaran TIK memang bukan menjadi sebuah kewajiban dari pemerintah untuk dipelajari, tetapi pihak sekolah merasa perlu siswanya dibekali ilmu dasar mengingat bahwa beberapa sekolah atau SMA lain sudah memasukkan pembelajaran desain web ke dalam kurikulum pembelajaran. Di samping itu, SMA Brigjend Katamso sendiri sudah memiliki website tetapi website tersebut adalah website Yayasan yang digunakan hanya untuk tujuan promosi. Sementara, sekolah tersebut memiliki banyak mitra dan dapat lebih memanfaatkan website yang bersifat informatif kepada para mitra. Untuk diketahui website sekolah juga menyediakan pengaturan pendidikan dengan kesempatan untuk mengubah dan meningkatkan pengalaman sekolah (Taddeo \& Barnes, 2016). Hal ini juga sejalan dengan pengabdian pada masyarakat yang dilakukan oleh (Supriyono et al., 2016) dan (Lestari \& Puspaningrum, 2017) bahwa website juga memberikan keuntungan yang bersifat intangible dan memungkinkan informasi dan prestasi sekolah bisa diakses oleh masyarakat kapan saja dimana saja selama ada jaringan internet tanpa terbatas jangkauan ruang dan waktu layaknya promosi dengan menggunakan material cetakan seperti leaflet atau spanduk. Harapannya dengan pembekalan ini, siswa dapat memanfaatkannya untuk berperan serta mendesain situs web sekolah mereka sendiri dan memiliki prestasi di bidang TIK.

Pihak IbM memilih Adobe Dreamweaver pada pelatihan kali ini karena fitur dari Adobe Dreamweaver mudah dipelajari, digunakan dan dipahami oleh anak-anak tingkat SMA dibandingkan dengan aplikasi atau bahasa-bahasa markah lain seperti HTML, CSS atau bahkan CMS. Dengan menggunakan Adobe Dreamweaver, siswa cukup mudah menggunakan tools yang tersedia, sebab jika menggunakan aplikasi lain, misalnya CMS maka siswa-siswa tersebut harus terlebih dahulu dibekali ilmu web dasar yang dikaitkan dengan pemahaman proses bisnis yang tentu saja untuk kondisi mitra saat ini belum memungkinkan karena siswa tersebut memang belum memiliki bekal ilmu web dasar, hal ini selaras dengan pernyataan pada pengabdian yang dilakukan oleh (Dharmawati, 2020), jika penggunaan metode dan media yang tepat dapat memberi stimulus bagi siswa untuk belajar aktif dan kreatif dan tentunya memiliki motivasi untuk meningkatkan pengetahuan mereka sesuai dengan bidang yang mereka pelajari.

\section{METODE}

Pelatihan ini dilaksanakan selama 2 hari dari pukul 13.30 wib s.d 16.30 wib kepada 43 siswa di hari pertama dan 38 siswa di hari kedua. Sebelum pelatihan dimulai, siswa diberi latihan dalam bentuk pre-test untuk mengukur kemampuan siswa dalam materi web dasar. Kemudian siswa mempraktikkan secara langsung materi yang telah dijelaskan berdasarkan modul pelatihan yang telah disusun oleh tim IbM. Praktik yang dilakukan diarahkan untuk mengembangkan ide pada desain website sekolah. Setelah pelatihan usai, siswa diberikan sesi latihan untuk melakukan test dengan mendesain website sekolah dengan menambah fitur-fitur web sekolah yang bertujuan untuk menguji/melihat sejauh mana siswa memahami materi yang telah dijelaskan sebelumnya. Dengan mengikuti pelatihan ini, siswa mampu membuat desain web sekolah menggunakan tools yang telah diajarkan pada pelatihan dengan mengembangkan ide mereka masing-masing. Di akhir 
kegiatan pelatihan, siswa mengisi post-test untuk mengukur kemampuan siswa setelah mengikuti pelatihan dan mengisi kuisoner pelatihan untuk mengukur kualitas dan kepuasan pelatihan yang telah dilaksanakan.

\section{HASIL DAN PEMBAHASAN}

Adapun pelaksanaan kegiatan yang telah dilakukan dijelaskan dengan urutan hari pelaksanaan, yaitu sebagai berikut:

1. Pelatihan Hari 1

Pada hari pertama pelaksanaan pelatihan web dasar kegiatan diawali dengan pembukaan oleh pihak pengabdian dan dilanjutkan oleh pihak SMA Brigjend Katamso. Pada hari pertama ini dilakukan pula absensi peserta dan dilanjutkan dengan pemberian pre-test untuk mengukur sejauh mana siswa/i tersebut mengenal konsep web. Setelah pre-test dilakukan, maka pemaparan materi dasar perancangan situs web sekolah dilakukan oleh tim dengan mengacu pada bahan ajar yang telah disediakan

2. Pelatihan Hari 2

Pada hari kedua pelaksanaan pelatihan desain situs web ini, kegiatan pelaksanaan juga dimulai dengan absensi peserta. Pada sesi ini, sebelum materi lanjutan disampaikan, tim IbM melakukan review materi yang telah disampaikan pada pertemuanhari pertama dan dilanjutkan dengan pemaparan materi lanjutan yaitu desain lanjutan. Selain kegiatan pengajaran materi, pada akhir pelaksanaan di hari kedua ini juga diberikan latihan khusus untuk menguji sejauh mana pemahaman siswa/i peserta pelatihan atas materi yang sudah disampaikan sebelumnya. Latihan yang diberikan adalah mengulang kembali materi yang telah dipaparkan dari pertemuan pertama sampai pertemuan kedua dengan memperhatikan semua aspek yang telah dijelaskan sebelumnya. Seperti seberapa mampu mereka bekerja dengan halaman web, teks dan gambar, mengolah media dalam Dreamweaver dan bekerja dengan berbagai Behavior dan Objek Spry yang telah dijelaskan selama pelatihan berlangsung. Hal ini membuktikan bahwa ketika melakukan desain "faktor desain web dapat mengubah persepsi pengguna terhadap situs web yang tidak semata-mata hanya untuk mencari konten informasi tetapi juga berkaitan dengan semua objek yang ada di dalam 1 halaman web dan jumlah eksposur yang dapat disediakan oleh objek itu kepada pengguna (McCoy, et al, 2017). Dari hasil test tersebut dipilih 3 desain terbaik dan desain tersebut juga ditampilkan ke semua peserta. Selain itu, peserta pelatihan juga mengisi form kuesioner yang dibagikan oleh tim pengabdian untuk melihat apa saja respon dari para peserta pelatihan atas hasil pelaksanaan kegiatan pengabdian pada masyarakat ini. Pertanyaan dalam form kuesioner disusun dalam skala Likert 5.

Berikut merupakan hasil rekapitulasi dari form kuesioner yang digunakan pada pelatihan desain situs web sekolah tersebut yang melibatkan 38 orang peserta yang datanya dapat diolah adalah 36 data saja, karena 2 data diantaranya tidak valid/ditemukan ada beberapa field isian kuesioner yang kosong (bentuk form kuesioner dapat dilihat pada halaman lampiran).

Tabel 1 Hasil Pengolahan Kuesioner Pengabdian Pada Masyarakat

\begin{tabular}{lcccccc}
\hline Kategori & \multicolumn{7}{c}{ Skala Penilaian } & Rata-Rata \\
& 1 & 2 & 3 & 4 & 5 & \\
\hline Pelaksanaan & & & & & & \\
Durasi Pelaksanaan & 0 & 2 & 5 & 14 & 15 & 4.17 \\
\multirow{2}{*}{ Perlengkapan Pelaksanaan } & $0 \%$ & $6 \%$ & $14 \%$ & $39 \%$ & $42 \%$ & \\
& 0 & 1 & 8 & 9 & 18 & 4.22 \\
& $0 \%$ & $3 \%$ & $22 \%$ & $25 \%$ & $50 \%$ & \\
\hline
\end{tabular}




\begin{tabular}{|c|c|c|c|c|c|c|}
\hline \multicolumn{7}{|c|}{ Fasilitator } \\
\hline Komunikatif \& Interaktifnya & 0 & 0 & 3 & 7 & 26 & 4.64 \\
\hline Fasilitator & $0 \%$ & $0 \%$ & $8 \%$ & $19 \%$ & $72 \%$ & \\
\hline \multirow{4}{*}{$\begin{array}{l}\text { Keramahan, Kesiapan } \\
\text { Keramahan Fasilitator } \\
\text { Penguasaaan Materi }\end{array}$} & 0 & 0 & 1 & 4 & 31 & 4.83 \\
\hline & $0 \%$ & $0 \%$ & $3 \%$ & $11 \%$ & $86 \%$ & \\
\hline & 0 & 0 & 7 & 10 & 19 & 4.33 \\
\hline & $0 \%$ & $0 \%$ & $19 \%$ & $28 \%$ & $53 \%$ & \\
\hline \multirow[t]{3}{*}{ Penampilan Fasilitator } & 0 & 1 & 1 & 8 & 26 & 4.64 \\
\hline & $0 \%$ & $3 \%$ & $3 \%$ & $22 \%$ & $72 \%$ & \\
\hline & Materi & Pemb & lajarar & & & \\
\hline \multirow[t]{2}{*}{ Kelengkapan Materi } & 0 & 2 & 5 & 9 & 20 & 4.31 \\
\hline & $0 \%$ & $6 \%$ & $14 \%$ & $25 \%$ & $56 \%$ & \\
\hline \multirow[t]{2}{*}{ Kemudahan Materi } & 0 & 0 & 10 & 12 & 14 & 4.11 \\
\hline & $0 \%$ & $0 \%$ & $28 \%$ & $33 \%$ & $39 \%$ & \\
\hline \multirow[t]{2}{*}{ Manfaaat Materi } & 0 & 0 & 0 & 7 & 29 & 4.81 \\
\hline & $0 \%$ & $0 \%$ & $0 \%$ & $19 \%$ & $81 \%$ & \\
\hline
\end{tabular}

Tabel 1 diatas menampilkan hasil pengolahan kuesioner yang merupakan kuesioner yang diisi oleh 36 orang siswa peserta pelatihan pada hari yang kedua. Kuesioner ini disusun dengan skala 1 sampai 5 dengan ketentuan yaitu: 1 sebagai indikator yang paling rendah (sangat tidak baik) hingga 5 sampai indikator yang paling tinggi (sangat baik).

Berikut kesimpulan yang dapat diambil dari hasil pengolahan data kuesioner tersebut:

1. Dari sisi pelaksanaan, dilihat dari durasi waktu dan perlengkapan yang memadai atau tidak, maka dapat diambil kesimpulan bahwa pelaksanaan pada pelatihan desain website ini adalah baik dengan nilai rata-rata yaitu $>4$

2. Dari sisi fasilitator, dilihat dari aspek komunikatif dan interaktifnya fasilitator, keramahan, kesiapan dan ketanggapan fasilitator, serta penguasaan materi dan penampilan fasilitator maka disimpulkan bahwa selama melaksanakan pelatihan, fasilitator berhasil membangun interaksi yang baik pula sampai dengan hari kedua dengan para peserta pelatihan. Hal ini terlihat dari nilai rata-rata semua aspek yang ada pada sisi fasilitator yang bernilai $>4$

3. Dari sisi materi pembelajaran yang telah disampaikan oleh tim IbM, peserta mendapatkan kesan bahwa materi pembelajaran yang dibagikan adalah lengkap, mudah dipahami dan memberikan manfaat bagi para peserta dan para peserta cukup antusias untuk mengikuti pelatihan tersebut dan memperoleh nilai rata-rata $>4$ pula. Hal ini juga terlihat dari hasil desain mereka yang cukup bagus sekalipun mengikuti pelatihan seperti ini untuk pertama kalinya.

Dari hasil 38 siswa yang mengikuti pelatihan selama dua hari, maka dari penilaian pre-test dan post-test diperoleh bahwa seluruh siswa yang mengikuti pelatihan ini memiliki minat di bidang komputer dan desain web. Rata-rata nilai pre-test 2,06 dan rata-rata nilai post-test 2,86. Hal ini menandakan adanya peningkatan pengetahuan siswa. Dari 38 nilai pengetahuan yang dievaluasi terdapat 11 siswa yang tidak memiliki peningkatan nilai dan 27 siswa memiliki peningkatan nilai. Dari sisi keterampilan 7 siswa tidak merasa adanya penambahan keterampilan secara signifikan sementara 31 siswa merasa adanya penamabahan keterampilan setelah mengikuti pelatihan. Hal ini sejalan dengan pernyataan: "Jika skor seseorang meningkat setelah diberikan pre-test dan post-test, hal ini merupakan dampak/efek diberikannya latihan/treatment kepada objek yang diuji (Knapp, 2016). 


\section{KESIMPULAN}

Pelaksanaan kegiatan pelatihan desain situs web dasar dengan Dreamweaver ini telah selesai dan terlaksana dengan baik di SMA Brigjend Katamso selama 2 hari oleh tim pengabdian. Dalam pelaksanaan kegiatan pelatihan ini, sebagian besar peserta pelatihan merasakan manfaat dari pelatihan dan para peserta antusias serta berpartisipasi dalam mengikuti semua rangkaian pelaksanaan kegiatan. Hal ini terlihat dari keaktifan mereka dalam menyelesaikan praktik dan post-test yang diberikan oleh tim IbM sampai dengan sesi akhir di hari ke dua. Dengan demikian maka dapat diambil kesimpulan bahwa pelaksanaan kegiatan pelatihan ini dinyatakan berhasil dan metode pembelajaran yang baik akan memberikan dampak baik pula pada peserta pelatihan.

\section{UCAPAN TERIMA KASIH}

Penulis mengucapkan terima kasih kepada Pusat Penelitian dan Pengabdian pada Masyarakat (P3M) STMIK Mikroskil dan sekolah mitra yang telah memberi dukungan financial terhadap pengabdian ini melalui hibah internal.

\section{DAFTAR PUSTAKA}

Dapodikbud. (2020). Sekolah Kita. Retrieved from http://sekolah.data.kemdikbud.go.id/index.php/chome/profil/E299916B-226F-4C89 9A60A52C2F119CB5

Dharmawati, D. (2020). Pembelajaran Berbasis Komputer Menggunakan Ms. Office 2019 Pada Siswa Di Smk Dwitunggal 1 Tanjung Morawa. Dinamisia: Jurnal Pengabdian Kepada Masyarakat, 4(1). https://doi.org/10.31849/dinamisia.v4i1.3751

Hendra Kurniawan. (2019). Literasi Digital bagi Generasi Milenial Melalui Website, 103-111.

Katamso, Y. P. B. (2020). Prestasi Yayasan Perguruan Brigjend Katamso. Retrieved from Yayasan Perguruan Brigjend Katamso

Kemdikbud. (2020). Data Sekolah. Retrieved from http://sekolah.data.kemdikbud.go.id/index.php/chome/profil/F7F5C055-F6B9-4D6998B3-193E57475562

Knapp, T. R. (2016). Why Is the One-Group Pretest-Posttest Design Still Used? Clinical Nursing Research, 25(5), 467-472. https://doi.org/10.1177/1054773816666280

Lestari, K., \& Puspaningrum, E. Y. (2017). Website Profil Sebagai Sarana Pengenalan Sekolah Dengan Pemrogaman PHP dan MySQL, XII(1), 13-18.

McCoy, S., Everard, A., Galletta, D. F., \& Moody, G. D. (2017). Here we go again! The impact of website ad repetition on recall, intrusiveness, attitudes, and site revisit intentions. Information and Management, 54(1), 14-24. https://doi.org/10.1016/j.im.2016.03.005

Supriyono, H., Sutopo, A., Nursyahid, H., Kurniawan, B. A., Fahrudin, I. N., Handoko, D., ... Kurniawan, D. C. (2016). Penerapan Teknologi Web Sekolah Bagi Smp Dan Sma Muhammadiyah Kartasura. Warta LPM, 19(1), 39-52. https://doi.org/10.23917/warta.v19i1.1983

Taddeo, C., \& Barnes, A. (2016). The school website: Facilitating communication engagement and learning. British Journal of Educational Technology, 47(2), 421-436. https://doi.org/10.1111/bjet.12229 